\title{
A national survey on attitudes and barriers on recycling and environmental sustainability efforts among Canadian anesthesiologists: an opportunity for knowledge translation Enquête nationale sur les attitudes et obstacles envers le recyclage et les efforts pour la protection de l'environnement parmi les anesthésiologistes canadiens : une opportunité de transfert des connaissances
}

\author{
Maria-Alexandra Petre, MD, FRCPC • Lisa Bahrey, MD, FRCPC • \\ Mark Levine, MBBCh, DA, FRCPC • Adriaan van Rensburg, MBChB, FRCPC · \\ Mark Crawford, MBBS, FRCPC $\cdot$ Clyde Matava, MBChB, DA, MMed
}

Received: 26 March 2018/Revised: 13 August 2018/Accepted: 10 October 2018/Published online: 13 December 2018

(c) Canadian Anesthesiologists' Society 2018

\begin{abstract}
Background Anesthesia-related activities produce $25 \%$ of all operating room (OR) waste and contribute to environmental pollution and climate change. The aim of this study was to document Canadian anesthesiologists' current practice, attitudes towards, and perceived barriers regarding recycling of $O R$ waste and environmental sustainability efforts.

Methods With Research Ethics Board approval, members of the Canadian Anesthesiologists' Society (CAS) completed an online survey consisting of 25 questions assessing current environmentally sustainable practices in
\end{abstract}

\footnotetext{
M.-A. Petre, MD, FRCPC

Department of Anesthesia, Faculty of Medicine, University of Toronto, Toronto, ON, Canada

L. Bahrey, MD, FRCPC - A. van Rensburg, MBChB, FRCPC Department of Anesthesia, Faculty of Medicine, University of Toronto, Toronto, ON, Canada

Department of Anesthesia, Toronto General Hospital, University Hospital Network, Sunnybrook, Toronto, ON, Canada

M. Levine, MBBCh, DA, FRCPC - M. Crawford, MBBS, FRCPC · C. Matava, MBChB, DA, MMed $(\square)$

Department of Anesthesia, Faculty of Medicine, University of Toronto, Toronto, ON, Canada

e-mail: Clyde.matava@sickkids.ca
}

Department of Anesthesia and Pain Medicine, The Hospital for Sick Children, Toronto, ON M5G 1X8, Canada anesthesiology and gaps, barriers, and interest in gaining further knowledge on this topic.

Results Four hundred and twenty-six of 2,695 (16\%) CAS members responded to the questionnaire. Despite a willingness to recycle at work among most anesthesiologists (393/403, 97.5\%), only 122/403 (30.2\%) did so. Other sustainability efforts in Canadian ORs included donating unused medical equipment and supplies to medical missions $(198 / 400,49.5 \%)$ and evening shut-off of anesthesia machines and other OR equipment $(185 / 400,46.3 \%)$. Reported barriers to recycling in the OR included a lack of support from hospital/OR leadership $(254 / 400,63.5 \%)$ and inadequate information/education (251/400, 62.8\%). Only 122/389 (31.4\%) of respondents were aware of any efforts to expand sustainability programs at their institutions but 273/395 (69.1\%) of respondents indicated an interest in obtaining further education on the topic.

Conclusion Canadian anesthesiologists appear ready to incorporate environmental sustainability in their practice but indicate that significant barriers exist. Our study highlights the need for further educational programs and implementation strategies.

\section{Résumé}

Contexte Les activités liées à l'anesthésie produisent $25 \%$ de tous les déchets en salle d'opération et contribuent à la pollution de l'environnement et au changement climatique. Le but de cette étude était de 
documenter les pratiques actuelles des anesthésiologistes canadiens, leurs attitudes envers le recyclage des déchets de salle d'opération et les efforts pour la protection de l'environnement, ainsi que les obstacles perçus comme s'y opposant.

Méthodes Après approbation d'un Comité d'éthique de la recherche, les membres de la Société canadienne des anesthésiologistes (SCA) ont pu remplir une enquête en ligne comportant 25 questions évaluant les pratiques actuelles en anesthésiologie pour un environnement durable ses obstacles, ses lacunes, ainsi que l'intérêt à en savoir plus sur ce sujet.

Résultats Quatre cent vingt-six des 2695 membres (16\%) de la SCA ont répondu au questionnaire. Malgré un désir de recyclage dans le cadre du travail chez la plupart des anesthésiologistes (393/403, 97,5\%), seulement 122/403 $(30,2 \%)$ le faisaient. D'autres efforts des salles d'opération canadiennes en faveur de la durabilité incluaient le don de l'équipement médical et des fournitures non utilisés à des missions médicales (198/ 400, 49,5\%) et la fermeture des appareils d'anesthésie et des autres équipements de la salle d'opération le soir (185/ 400, 46,3\%). Les obstacles au recyclage en salle d'opération qui ont été mentionnés incluaient une absence de soutien de la part du leadership de l'hôpital/ de la salle d'opération (254/400, 63,5\%) et une information/éducation insuffisante sur le sujet (251/400, $62,8 \%)$. Seulement 122 des 389 répondants $(31,4 \%)$ étaient au courant d'efforts d'extension des programmes en faveur de l'environnement, mais $273 / 395$ (69,1\%) répondants ont manifesté de l'intérêt à obtenir plus de formation sur le sujet.

Conclusion Les anesthésiologistes canadiens semblent prêts à incorporer la protection de l'environnement dans leurs pratiques, mais indiquent qu'il existe des obstacles significatifs. Notre étude souligne le besoin de poursuivre les programmes éducatifs et les stratégies de mise en ouvre.

Global warming and environmental degradation pose a significant threat to public health. ${ }^{1}$ Unfortunately, healthcare services, including anesthesia, have been identified as significant contributors to climate change. Recent estimates place this contribution to the total greenhouse gas emissions by healthcare services in Canada and the United States at $1.1 \%$ and $9.8 \%$, respectively. $^{2,3}$ In addition, healthcare activities contribute significantly to other forms of pollution, such as acidification, smog formation, release of carcinogenic and non-carcinogenic air toxins, and being responsible for as many as 470,000 disability-adjusted life-years lost in the US in 2013 alone. $^{3}$

Given the significant environmental impact of healthcare-related activities, much research has been devoted to improving the environmental sustainability of healthcare provision, such as hospital design, decreasing energy and water usage, and reducing waste production. In addition, procurement practices also take into account each product's and pharmaceutical's environmental footprint throughout its life-cycle, improving the way healthcare providers interact with and travel to and from healthcare facilities, and decreasing healthcare utilization through healthcare prevention. ${ }^{4}$

One area of much focus has been operating room (OR) waste production. While ORs represent a very small portion of the surface area within their respective hospitals, they are responsible for a disproportionately large percentage (20\%$30 \%$ ) of the $>6,000$ tons of medical waste produced daily in the US. A quarter of this waste is anesthetic in origin, of which $40 \%$ is potentially recyclable. ${ }^{5}$ When included in a multipronged program targeting waste reduction, recycling successfully reduced the amount of waste produced at a variety of test healthcare organizations, with some recycling programs also showing a financial benefit. ${ }^{6,7}$ Indeed, recycling has several beneficial effects on environmental sustainability. For example, it decreases the amount of waste sent to landfills, reduces the amount of waste requiring energy-intensive and environmentally hazardous treatment, and provides a resource-efficient alternative to making products from raw materials. $^{8}$

In addition to recycling, other activities have been proposed to improve the environmental sustainability of anesthesia practice. These range from individual actions like biking/walking to work and using low-flow anesthesia, total intravenous anesthesia, reusable products, waste gas capture, and prefilled syringes, to team-based efforts such as reducing waste by engaging manufacturers and forming environmental working groups within individual institutions, among many others. ${ }^{9}$ While many of these may provide an economic as well as financial befit, it remains unclear how widely these practices have been adopted by healthcare institutions and what barriers impede implementation.

Surveys of anesthesiologists in Australia, New Zealand, England, and the United States indicate that, although there is a strong interest in recycling at work, few anesthesiologists do recycle. They perceive barriers that include inadequate recycling facilities, staff attitudes, and inadequate information on how to recycle. ${ }^{10,11}$ To date, no similar survey has been carried out in Canada.

The aim of this study was to ascertain Canadian anesthesiologists' current practices, attitudes towards, and 
barriers to OR room waste recycling and environmental sustainability efforts. It is hoped these findings will inform future recycling and environmental sustainability programs and educational resources for anesthesia departments. A further aim is to compare and contrast Canadian data with data gathered in the United States, New Zealand, Australia, and England. ${ }^{10,11}$

\section{Methodology}

Ethics, recruitment, and data collection

Approval for this study was obtained from the University of Toronto Research Ethics Board. The Canadian Anesthesiologists Society (CAS) Executive Board approved distribution of this survey among its members. An invitation letter with a link to Fluidsurvey.com was emailed by the CAS administrative office on behalf of the investigators to all members of the CAS, including trainees and staff anesthesiologists. A reminder email was sent two weeks later. The online survey remained open for one month after the last email had been sent. All responses were anonymous, and consent was implied by participation in the survey.

\section{Sample size}

Given a potential study population of approximately 3,000 anesthesiologists and trainees, the minimum sample size required was estimated a priori to be 341 participants for a margin of error of $5 \%$ with $95 \%$ confidence. ${ }^{12}$ Given the reported response rates experienced by other surveys of anesthesiologists, we anticipated an overall completed survey response rate in the range of $10-40 \%$; therefore, we invited all eligible CAS members $(n=2,695)$ to participate in the survey.

Study design

A literature review was conducted through MEDLINE and PubMed together with studies drawn from reference lists of relevant articles. Based on this literature review and consensus, a survey was developed to:

1. Ascertain attitudes towards and current practice in recycling of anesthesia-related OR waste as well as other environmental sustainability efforts;

2. Identify potential barriers to recycling of anesthesiarelated OR waste and other environmental sustainability efforts;

3. Explore a possible need for educational programs;
4. Compare responses of Canadian anesthesiologists to previously published surveys.

The questionnaire consisted of 25 multiple-choice, Likert scale, and free-text items assessing demographics (questions 1-6); value placed on environmental sustainability and prior education on this topic (questions 7-10); environmental sustainability efforts within anesthesia and barriers to these efforts (questions 11-20); personal and departmental plans regarding sustainability (questions 21-24); and a general feedback question (question 25). Questions 11-13, 18-19, and 21 were adapted from McGain et al. ${ }^{10}$ to allow comparisons between this study and previously identified evidence (Appendix).

\section{Survey validity testing}

The survey instrument was formally tested beforehand using a convenience sample of three anesthesia trainees and three staff anesthesiologists. Feedback indicated no significant changes were needed.

\section{Data analysis}

Data were collected and managed using Fluidsurvey.com, a secure online electronic data-capture tool hosted in Canada. Descriptive statistics were generated with Microsoft Excel as proportions of respondents. Because respondents had the option of skipping questions, all proportions are relative to the number of respondents for each question. Where appropriate and for ease of reporting, data for similar Likert scale categories were combined.

\section{Results}

Demographics of respondents

The number of responses (426; $16 \%$ response rate) exceeded the minimum sample size estimated for the study (341 responses). Most respondents were staff anesthesiologists working in university/academic practice 252/403 (62.5\%) with the most commonly represented bracket for years in practice being 21-30 yr (107/405, 26.4\%, Table 1).

Current attitudes and practice in environmentally sustainable anesthesiology

Most respondents $(357 / 403,88.6 \%)$ indicated that they agreed or strongly agreed that the environmental impact of anesthesia-related products and procedures are important 
Table 1 Demographic characteristic of respondents

\begin{tabular}{|c|c|}
\hline Characteristic & $n(\%)$ \\
\hline \multicolumn{2}{|l|}{ Age $(n=406)$} \\
\hline$<30$ & $21(5.2)$ \\
\hline $30-49$ & $204(50.2)$ \\
\hline $50-64$ & $156(38.4)$ \\
\hline$\geq 65$ & $25(6.2)$ \\
\hline \multicolumn{2}{|l|}{ Province/territory $(n=406)$} \\
\hline Alberta & $51(12.6)$ \\
\hline British Columbia & $46(11.3)$ \\
\hline Manitoba & $17(4.2)$ \\
\hline New Brunswick & $14(3.4)$ \\
\hline Newfoundland and Labrador & $4(1.0)$ \\
\hline Northwest Territories & $0(0)$ \\
\hline Nova Scotia & $20(4.9)$ \\
\hline Nunavut & $0(0)$ \\
\hline Ontario & $191(47.0)$ \\
\hline Prince Edward Island & $1(0.2)$ \\
\hline Quebec & $52(12.8)$ \\
\hline Saskatchewan & $10(2.5)$ \\
\hline Yukon & $0(0)$ \\
\hline \multicolumn{2}{|l|}{ Facility type $(n=403)$} \\
\hline Community & $35(8.7)$ \\
\hline Community/teaching & $104(25.8)$ \\
\hline University/academic & $252(62.5)$ \\
\hline Other & $12(3.0)$ \\
\hline \multicolumn{2}{|l|}{ Role $(n=405)$} \\
\hline Staff & $333(82.2)$ \\
\hline Resident & 48 (11.9) \\
\hline Fellow & $13(3.2)$ \\
\hline Anesthesia assistant & $11(2.7)$ \\
\hline Medical student & $0(0)$ \\
\hline \multicolumn{2}{|c|}{ Number of years in practice $(n=405)$} \\
\hline 1-2 (Junior resident) & $16(4.0)$ \\
\hline 3-5 (Senior resident) & $31(7.7)$ \\
\hline 6-10 (Fellow/junior staff) & $58(14.3)$ \\
\hline $11-15$ & $78(19.3)$ \\
\hline $16-20$ & $52(12.8)$ \\
\hline $21-30$ & $107(26.4)$ \\
\hline$>30$ & $63(15.6)$ \\
\hline
\end{tabular}

factors that should be considered when conducting anesthesia practice.

Nearly all respondents, 393/403 (97.5\%), also either agreed or strongly agreed that they recycled at home. Furthermore, while 382/403 (94.8\%) would like to recycle anesthesia waste, only $122 / 403(30.3 \%)$ reported that anesthesia waste was recycled in their hospital (Table 2). The two most commonly recycled items were cardboard/paper and batteries (Table 3). Nevertheless, 70/
$401(17.5 \%)$ indicated their OR did not recycle and 59/401 $(14.7 \%)$ indicated they did not know which products were recycled in the OR (Table 3 ).

Beyond recycling, 217/402 (54.0\%) of respondents agreed or strongly agreed that they considered environmental impact when choosing anesthetic agents (pharmaceutical agents, including managing fresh gas flows and carrier gases), and 178/402 (44.3\%) considered environmental impact when choosing non-pharmaceutical products (gowns, supraglottic airways [SGAs]), circuits etc.) related to anesthesia. Other reported sustainability measures include donating unused medical equipment and supplies to medical missions (198/400, 49.5\%); evening shut-off of the anesthesia machine and other equipment in the OR $(185 / 400,46.2 \%)$; appropriate segregation of biohazardous and nonhazardous waste (175/400, 43.8\%); and choosing anesthetic gases on the basis of their environmental impact (163/400, 40.8\%) (Table 4). Most respondents were unaware of any future departmental plans to increase sustainability $(267 / 389,68.6 \%)$, but some indicated that their department had plans to increase efforts in specific areas, including appropriate segregation of biohazardous and nonhazardous waste 56/389 (14.4\%); evening shut-off of anesthesia machines and other OR equipment $(54 / 389,13.9 \%)$; choosing anesthetic gases based on their environmental footprint (53/389, 13.6\%); and recycling $(49 / 389,12.6 \%)$ (Table 4$)$.

\section{Barriers to environmentally sustainable practice}

The most commonly reported perceived barriers to recycling included a perceived lack of support from hospital and OR leadership (254/400, 63.5\%); inadequate information or education $(251 / 400,62.8 \%)$; staff attitudes (209/400, 52.2\%); and lack of recycling facilities (206/400, $51.5 \%$ ) (Tables 2 and 5). Some respondents provided comments highlighting concerns about infection control and contamination of recyclable materials with biologic fluids.

Commonly identified barriers to sustainability efforts other than recycling (e.g., choosing anesthetic gases based on their environmental footprint) included inadequate information or education $(211 / 400,52.8 \%)$ and lack of support from hospital and OR leadership (193/400, 48.2\%) (Table 5).

Education and strategies to increase recycling and sustainability

Only $182 / 403(45.2 \%)$ of respondents agreed or strongly agreed that their level of knowledge about the environmental impact of anesthesia-related agents, products, and procedures was sufficient to guide their 
Table 2 Attitudes and barriers reported using similar surveys among members of the Canadian Anesthesiologists' Society (CAS), the National Health Services of England (NHS), the Australian and New Zealand College of Anesthetists (ANZCA), and the American Society of Anesthesiologists (ASA).

\begin{tabular}{|c|c|c|c|c|}
\hline $\begin{array}{l}\text { Survey statement (agree or strongly } \\
\text { agree) }\end{array}$ & $\begin{array}{l}\text { CAS } \\
n=403\end{array}$ & $\begin{array}{l}\text { NHS }^{10} \\
n=570\end{array}$ & $\begin{array}{l}\text { ANZCA }^{10} \\
n=210\end{array}$ & $\begin{array}{l}\text { ASA }^{11} \\
n=2036\end{array}$ \\
\hline I recycle at home & $393(98)$ & $541(96)$ & $198(94)$ & 1455 of $1787(81)$ \\
\hline $\begin{array}{l}\text { Anesthesia waste is recycled in the } \\
\text { operating rooms I usually work in }\end{array}$ & $122(30)$ & $66(12)$ & $21(10)$ & 497 of $1791(28)$ \\
\hline $\begin{array}{l}\text { I would like to recycle operating room } \\
\text { waste }\end{array}$ & $382(95)$ & $530(94)$ & $193(92)$ & 1431 of 1786$)(80)$ \\
\hline $\begin{array}{l}\text { What do you perceive as barriers to } \\
\text { recycling in operating rooms? }\end{array}$ & $\begin{array}{l}\text { 1. Lack of support from hospital/ } \\
\text { OR leadership }(254 / 400,63.5 \%) \\
\text { 2. Inadequate information on } \\
\text { recycling }(251 / 400,62.8 \%) \\
\text { 3. Staff attitudes }(209 / 400,52.2 \%)\end{array}$ & $\begin{array}{l}\text { 1. Inadequate } \\
\text { recycling facilities } \\
\text { 2. Inadequate } \\
\text { information on } \\
\text { recycling } \\
\text { 3. Staff attitudes }\end{array}$ & $\begin{array}{l}\text { 1. Lack of recycling } \\
\text { facilities } \\
\text { 2. Inadequate } \\
\text { information on } \\
\text { recycling } \\
\text { 3. Staff attitudes }\end{array}$ & $\begin{array}{l}\text { 1. Inadequate } \\
\text { information on } \\
\text { recycling } \\
\text { 2. Lack of recycling } \\
\text { facilities } \\
\text { 3. Staff attitudes }\end{array}$ \\
\hline $\begin{array}{l}\text { Which of the following is the greatest } \\
\text { barrier to recycling? }\end{array}$ & $\begin{array}{l}\text { Lack of support from hospital/OR } \\
\text { leadership }(130 / 400,32.5 \%)\end{array}$ & $\begin{array}{l}\text { Lack of recycling } \\
\text { facilities }\end{array}$ & $\begin{array}{l}\text { Lack of recycling } \\
\text { facilities }\end{array}$ & $\begin{array}{l}\text { Inadequate } \\
\text { information on } \\
\text { recycling }\end{array}$ \\
\hline \multicolumn{5}{|c|}{ To increase recycling (sustainability in CAS survey) in operating rooms, I am willing to provide one of the following (select one or more) ${ }^{*}$} \\
\hline Time to educate myself & $340(85)$ & $(71 \%)$ & $(82 \%)$ & $(73.9 \%)$ \\
\hline Time to educate others & $231(58)$ & $(56 \%)$ & $(56 \%)$ & $(49.9 \%)$ \\
\hline Funds to educate myself & $60(15)$ & $(5.3 \%)$ & $(8.8 \%)$ & $(8.0 \%)$ \\
\hline Funds to educate others & $31(8)$ & $(3.1 \%)$ & $(7.4 \%)$ & $(6.9 \%)$ \\
\hline
\end{tabular}

Data are reported as counts $(\%)$ as reported in the references indicated. Note that responses to questions regarding willingness to provide time or funds were reported as percentages without numerator or denominator data in references ${ }^{10}$ and ${ }^{11}$

Table 3 Products recycled in the operating room

\begin{tabular}{lc}
\hline & $n=401(\%)$ \\
\hline Cardboard/paper & $219(54.6)$ \\
Batteries & $189(47.1)$ \\
Plastics & $163(40.6)$ \\
Glass & $53(13.2)$ \\
Electronics & $46(11.5)$ \\
Metal & $24(6.0)$ \\
Other & $30(7.5)$ \\
I don't know & $59(14.7)$ \\
We do not recycle & $70(17.5)$ \\
\hline
\end{tabular}

practice. Less than half of respondents (172/404, 42.6\%) indicated receiving prior formal training on the topic. The most common formats of prior exposure to the topic included independent reading $(107 / 200,53.5 \%)$, peer-topeer discussions $(87 / 200,43.5 \%)$, conference lectures (84/ 200, 42.0\%), and journal clubs $(33 / 200,16.5 \%)$ (Table 6).

To increase recycling in the OR, most respondents were willing to find time to educate themselves (340/398, $85.4 \%$ ) and to educate others $(231 / 398,58.0 \%)$. A few were willing to provide funds to educate themselves (60/ $398,15.1 \%)$ and funds to educate others $(31 / 398,7.8 \%)$
(Table 2). Many respondents indicated that they were either likely or very likely to seek more information on the topic of environmentally sustainable anesthesia practice (273/395, 69.1\%). Respondents identified formal curriculum during residency/fellowship training (242/394, $61.4 \%)$, conference lectures $(197 / 394,50.0 \%)$, peer-to-peer discussions $(184 / 394,46.7 \%)$, and online e-modules (182/ $394,46.2 \%)$ as the most valuable methods to increase awareness of recycling and environmental sustainability efforts among anesthesiologists (Table 6).

\section{Comments according to thematic approach}

There were 92 free-text comments, which were analyzed using a thematic approach into the following four themes:

1. Importance of addressing environmental sustainability;

2. Frustration with lack of environmental sustainability efforts at their institutions;

3. Perceived barriers and concerns regarding sustainability efforts such as concerns over patient safety and disease transmission, lack of anesthesiologist involvement in purchasing decisions, and lack of information/education on environmental practice;

4. Suggestions for improving environmental sustainability in the OR, such as ensuring that each 
Table 4 Current and planned sustainability efforts in the operating room

\begin{tabular}{|c|c|c|}
\hline & $\begin{array}{l}\text { Current } \\
n=400(\%)\end{array}$ & $\begin{array}{l}\text { Future } \\
n=389(\%)\end{array}$ \\
\hline Recycling & & $49(12.6)$ \\
\hline Donating unused medical equipment and supplies to medical missions & $198(49.5)$ & $52(13.4)$ \\
\hline Evening shut-off of anesthesia machines and other OR equipment & $185(46.2)$ & $54(13.9)$ \\
\hline Appropriate separation of biohazardous and nonhazardous waste & $175(43.8)$ & $56(14.4)$ \\
\hline Choosing anesthetic gases based on their environmental footprint & $163(40.8)$ & $53(13.6)$ \\
\hline Using reusable products (gowns, LMA, anesthesia circuits, etc.) instead of single-use products & $126(31.5)$ & $33(8.5)$ \\
\hline Using anesthetic gas capture/reflection modalities & $93(23.3)$ & $29(7.5)$ \\
\hline Reprocessing single-use medical equipment & $67(16.8)$ & $15(3.9)$ \\
\hline Using reusable sharps containers & $73(18.2)$ & $15(3.9)$ \\
\hline Using prefilled medication syringes & $45(11.2)$ & $31(8.0)$ \\
\hline Partnering with industry to promote greener packaging practices & $10(2.5)$ & $9(2.3)$ \\
\hline
\end{tabular}

LMA = laryngeal mask airway device

Table 5 Main barriers to recycling and other sustainable efforts

\begin{tabular}{|c|c|c|}
\hline & $\begin{array}{l}\text { Recycling } \\
n=400(\%)\end{array}$ & $\begin{array}{l}\text { Other } \\
\text { sustainability } \\
\text { efforts } \\
n=400(\%)\end{array}$ \\
\hline $\begin{array}{l}\text { Lack of support from } \\
\text { hospital/OR leadership }\end{array}$ & $254(63.5)$ & $193(48.2)$ \\
\hline Inadequate information/education & $251(62.8)$ & $211(52.8)$ \\
\hline Staff attitudes & $209(52.2)$ & $146(36.5)$ \\
\hline Lack of (recycling) facilities & $206(51.5)$ & $84(21.0)$ \\
\hline Cost & $146(36.5)$ & $146(36.5)$ \\
\hline Time & $107(26.8)$ & $81(20.2)$ \\
\hline Lack of space & $103(25.8)$ & $53(13.2)$ \\
\hline Safety & $64(16.0)$ & $59(14.8)$ \\
\hline
\end{tabular}

$\mathrm{OR}=$ operating room

anesthesia workstation includes a recycling bin; continued education or formal curriculum training; and making sustainability a hospital quality metric.

Examples of these are provided in Table 7.

\section{Discussion}

Our study provides a nationwide cross-sectional snapshot of Canadian anesthesiologists' attitudes towards, current efforts, and perceived barriers to recycling and environmental sustainability in their clinical practice. Our findings demonstrate interest among Canadian anesthesiologists in implementing environmentally sustainable anesthesia practices; nevertheless, several barriers exist.

Canadian anesthesiologists report a strong interest in recycling efforts in the OR; nevertheless, most do not do
Table 6 Format of prior education on sustainability and perceived most valuable methods of education on environmental sustainability efforts among anesthetists as identified by respondents

\begin{tabular}{lcc}
\hline & $\begin{array}{l}\text { Format of prior } \\
\text { education on } \\
\text { sustainability } \\
n=200(\%)\end{array}$ & $\begin{array}{l}\text { Perceived most valuable } \\
\text { methods of education on } \\
\text { sustainability } \\
n=394(\%)\end{array}$ \\
\hline $\begin{array}{l}\text { Formal curriculum } \\
\text { training }\end{array}$ & $18(9.0)$ & $242(61.4)$ \\
Conference lecture & $84(42.0)$ & $197(50.0)$ \\
Peer-to-peer discussions & $87(43.5)$ & $184(46.7)$ \\
Online e-module & $5(2.5)$ & $182(46.2)$ \\
Workshop & $6(3.0)$ & $114(28.9)$ \\
Journal club & $33(16.5)$ & $94(23.9)$ \\
Independent reading & $107(53.5)$ & $94(23.9)$ \\
Other & $43(21.5)$ & $29(7.4)$ \\
\hline
\end{tabular}

so. Previous studies have demonstrated that, at least in Australia, OR recycling programs are feasible, divert waste from landfills, and improve worker satisfaction without causing delays in the OR. ${ }^{5,13}$ Nevertheless, it is important to highlight that, because healthcare waste and recycling streams must undergo more thorough and energy-intensive disinfection processes than household waste, other methods of waste management, such as prevention, reduction, and reuse should also be maximized whenever possible and further investigations of the feasibility of these methods in the OR are required. ${ }^{14}$ Our findings demonstrate that, in addition to recycling, Canadian anesthesiologists engage in a variety of evidence-based environmental sustainability efforts including evening shut-off of anesthesia machines and other equipment in the OR, appropriate segregation of biohazardous and nonhazardous waste, and choosing anesthetic gases on the basis of their environmental 
Table 7 Current and planned sustainability efforts in the operating room

\begin{tabular}{|c|c|}
\hline Theme & Sample comments \\
\hline $\begin{array}{l}\text { Importance of addressing environmental } \\
\text { sustainability }(n=19)\end{array}$ & $\begin{array}{l}\text { I am so glad that this topic is being addressed and researched. We create so much waste on a } \\
\text { daily basis and I believe it will make a big difference to the environment if we educate } \\
\text { ourselves in "green habits", such as using sevo instead of Des, low gas flows, recycling, and } \\
\text { using reusable products. The idea of educating residents about this important aspect as they go } \\
\text { through residency appeals to me, and I believe that it will culture good habits that will be } \\
\text { collectively very beneficial to our environment. } \\
\text { We need to think more broadly of our contribution to health, thinking beyond our narrow } \\
\text { specialty and our direct work with patients. This is a great topic that I hope to hear more } \\
\text { about. } \\
\text { Please cover this important subject during all future CAS meetings. Thank you! }\end{array}$ \\
\hline $\begin{array}{l}\text { Frustration with lack of environmental } \\
\text { sustainability efforts }(n=13)\end{array}$ & It is disheartening that we are not able to recycle more due to multiple reasons. \\
\hline $\begin{array}{l}\text { Barriers to environmentally sustainable } \\
\text { practice }(n=24)\end{array}$ & $\begin{array}{l}\text { We need more/better information regarding the environmental footprint of single-use device } \\
\text { manufacturing, packaging, transportation, disposal } v s \text { impact of reprocessing. }\end{array}$ \\
\hline $\begin{array}{l}\text { Suggestions for future improving the process } \\
\quad(n=35)\end{array}$ & $\begin{array}{l}\text { A workshop (for existing staff) or formal curriculum training (for students/residents) is the best } \\
\text { way to educate on this topic in my opinion. } \\
\text { The largest improvement in recycling at our institution came when multiple recycling bins } \\
\text { became readily available in each theatre. } \\
\text { Include recycling etc. as part of accreditation to get the hospital/admin on board. } \\
\text { Audit hospitals and publish each hospitals score in multiple areas to improve and monitor } \\
\text { compliance. } \\
\text { Award high performing hospitals/departments. } \\
\text { Hold CME events based on environmental/recycling education and practice. } \\
\text { 1. Start with junior staff/residents-they will be more receptive and easier to mould } \\
\text { 2. Get buy in from the institutions (cost implications and we will need their support) } \\
\text { 3. Get local champions. } \\
\text { Providing practitioners with practical, proven suggestions/options to change their current } \\
\text { practice would have the most impact. } \\
\text { Need to involve others in addition to anesthesia. }\end{array}$ \\
\hline
\end{tabular}

CAS = Canadian Anesthesiologists' Society; CME = continuing medical education

impact. While these strategies are evidence based, they were partially implemented across the practices of anesthesiologists. This inconsistency could limit the efficacy of such efforts. Our study was unable to identify whether anesthesiologists in the same institution practiced these efforts to different extents. Furthermore, our study reveals the common practice of some approaches, such as the donation of medical equipment, which, if not practiced correctly, only serve to move rather than reduce waste, highlighting the need for continued research and knowledge translation in this field. ${ }^{15,16}$

While the practices and barriers to environmental sustainability appear to be similar between members of the CAS and those of previously published studies in the US, Australia, New Zealand, and England, the current study highlights the perceived "lack of support from hospital and OR leadership" as a considerable barrier to environmentally sustainable efforts in Canadian ORs. Gaining support from hospital and OR leadership might be encouraged at levels above the hospital administration, as some respondents suggested, by including sustainability efforts in hospital accreditation processes. Published carbon footprints indicate that measurement and comparison of hospital environmental sustainability efforts is possible, ${ }^{17,18}$ and benchmarking sustainability efforts may encourage dissemination of best practices among institutions. Independent of such oversight, hospital administrators can encourage the implementation of multidisciplinary OR "green teams", which bring together and empower OR staff to implement new initiatives in a collaborative environmentally and economically sustainable manner. These initiatives could overcome some of the psychologic barriers formed by complacency on this topic. ${ }^{19-23}$ 
Some respondents raised the question of disease transmission and patient safety of environmental practices. Previous studies revealed a lack of awareness of simple strategies such as appropriate waste segregation among anesthesiologists, ${ }^{11,13}$ and suggested that anesthesiologists must collaborate with hospital infection control teams to ensure rigorous quality control of reprocessing and recycling processes to avoid complications that might jeopardize patient safety and undermine waste-management initiatives. ${ }^{24-26}$ Furthermore, difficulties encountered with recycling and reprocessing underscore the importance of reduction strategies, such as collaborating with industry to reduce packaging included with each product and continuing materials science research that might yield biodegradable alternatives to commonly used products.

Furthermore, some respondents astutely raised concerns that the options included under the umbrella of "sustainable anesthesia practice" might not consider the full environmental impact of reprocessing reusable products. These concerns have, in some cases, been addressed by studies employing life-cycle assessment methods to conduct head-to-head comparisons between reusable and disposable alternatives of products, taking into account all the resources consumed and waste produced throughout the production, use, and disposal of each alternative. Life-cycle assessments have been applied to compare the environmental footprint of anesthetic pharmaceuticals, ${ }^{27}$ processes, ${ }^{28}$ and products. ${ }^{29-32}$ Some examples of commonly used products, which may be found in both reusable and single-use alternatives within the same OR, include SGAs and sterile gowns. For both of these, tabulating resource utilization and financial costs over a product's life-cycle indicated the reusable option would be both environmentally and economically sustainable. ${ }^{29,30}$

Most respondents indicated that the environmental impact of anesthesia is important and should inform clinical practice when choosing between products and processes that are otherwise equivalent in efficacy and patient outcomes. Nevertheless, most believed they have inadequate information to make environmentally friendly choices, which might be related to a relative paucity of formal education efforts on the topic. A large proportion of respondents indicated they wanted more information on environmental sustainability in anesthesia practice and would be willing to invest time to educate themselves and their peers on this topic. Thus, any knowledge gaps identified by this and previous studies might be filled by concerted efforts on behalf of anesthesiology representative bodies and educational programs to support developing, for example, residency curricula, conference seminars, e-modules, as well as consensus statements on the topic. While continued research is required to adequately guide practice, anesthesiology bodies such as the American Society of Anesthesiologists have already begun the process of building such guidelines. $^{33}$

Limitations of the current study include responder bias (the lack of a French version of our survey could have led to an underrepresentation of French-speaking anesthesiologists in our results) and an underrepresentation of remote provinces and territories (where geographical isolation and access to recycling facilities might present much bigger barriers to recycling and sustainability). Furthermore, respondents were primarily staff working in academic institutions, and might not be representative of the wider population of anesthesiologists in Canada.

In conclusion, our study has shown that despite strong interest from anesthesiologists on the topic, gaps remain in recycling and environmental sustainability measures within Canadian anesthesiology practice. We have highlighted barriers that might be overcome by further educational and leadership efforts.

Conflicts of interest None declared.

Editorial responsibility This submission was handled by Dr. Gregory L. Bryson, Deputy Editor-in-Chief, Canadian Journal of Anesthesia.

Author contributions Clyde Matava and Marie-Alexandra Petre contributed substantially to all aspects of this manuscript, including study conception and design, acquisition, analysis, and interpretation of data, and drafting the article. Mark Crawford, Lisa Bahrey, Mark Levine, and Adriaan van Rensburg contributed substantially to the conception and design of the manuscript.

\section{Appendix: Survey tool}




\section{Demographics}

1. What is your age range?
a. $<30$
b. $30-49$
c. $50-64$
d. $\geq 65$

2. Where is your facility located?
a. Alberta
b. British Columbia
c. Manitoba
d. New Brunswick
e. Newfoundland and Labrador
f. Northwest Territories
g. Nova Scotia
h. Nunavut
i. Ontario
j. Prince Edward Island
k. Quebec
1. Saskatchewan
m. Yukon

3. At what type of facility do you work?
a. Community
b. Community/teaching
c. University/academic
d. Other (please specify):

4. Are you a:
a. Anesthesia staff
b. Resident
c. Fellow
d. Medical student
e. Other (please specify): 
5. How many years have you been in anesthesia practice, including completed years of residency and fellowship?
a. 1-2 (Junior resident)
b. 3-5 (Senior resident)
c. $6-10$ (Fellow/junior staff)
d. $11-15$
e. $16-20$
f. $21-30$
g. $>30$

Value/knowledge

1. To what extent do you agree with the following statement: The environmental impact of anesthesia-related products and procedures is an important factor that should be taken into account when conducting anesthesia practice.

a. Strongly disagree - Disagree - Uncertain - Agree - Strongly agree

2. To what extent do you agree with the following statement: My level of knowledge on the environmental impact of anesthesia-related agents, products, and procedures is sufficient to guide my practice.

a. Strongly disagree - Disagree - Uncertain - Agree - Strongly agree

3. Have you received any training/education on environmental sustainability in anesthesia?

a. Yes/No

4. What format did this training take? (Select all that apply)
a. Formal curriculum during training
b. Workshop
c. Online e-module
d. Conference lecture
e. Journal club
f. Peer-to-peer discussions
g. Independent reading
h. Other (please specify):

Current practice 
To what extent do you agree or disagree with the following statements (items 5-9)

\begin{tabular}{|c|c|c|c|c|c|}
\hline & $\begin{array}{l}\text { Strongly } \\
\text { disagree }\end{array}$ & $\begin{array}{l}\text { Disagre } \\
\mathrm{e}\end{array}$ & $\begin{array}{l}\text { Uncertai } \\
\mathrm{n}\end{array}$ & Agree & $\begin{array}{l}\text { Strongl } \\
\text { y agree }\end{array}$ \\
\hline 5. I recycle at home & & & & & \\
\hline $\begin{array}{l}\text { 6. Anesthesia waste is recycled in the } \\
\text { OR I usually work in }\end{array}$ & & & & & \\
\hline $\begin{array}{l}\text { 7. I would like to recycle anesthesia } \\
\text { waste }\end{array}$ & & & & & \\
\hline $\begin{array}{l}\text { 8. I consider the environmental } \\
\text { impact when choosing anesthetic } \\
\text { agents }\end{array}$ & & & & & \\
\hline $\begin{array}{l}\text { 9. I consider the environmental } \\
\text { impact when choosing products } \\
\text { used to conduct anesthetics (gowns, } \\
\text { LMAs, circuits etc.) }\end{array}$ & & & & & \\
\hline
\end{tabular}

10. What products are recycled in your OR?
a. I don't know
b. Cardboard/paper
c. Glass
d. Plastics
e. Metal
f. Batteries
g. Electronics
h. Other (please specify):
i. We do not recycle

11. Besides recycling, has your anesthesia department undertaken any other sustainability efforts?

a. Choosing anesthetic gases based on their environmental footprint (including managing fresh gas flows and carrier gases)

b. Using anesthetic gas capture/reflection modalities

c. Using prefilled medication syringes

d. Using reusable products (gowns, LMA, anesthesia circuits, etc.) instead of singleuse products

e. Reprocessing single-use medical equipment

f. Using reusable sharps containers

g. Donating unused medical equipment and supplies to medical missions

h. Partnering with industry to promote greener packaging practices

i. Appropriate segregation of biohazardous and nonhazardous waste

j. Evening shut-off of anesthesia machine and other equipment in the OR 
k. I am not aware of any such efforts

1. Other: (free text)

Barriers to sustainability

12. Which of the following do you perceive as potential barriers to recycling in the OR? (choose all that apply)
a. Staff attitudes
b. Cost
c. Inadequate information/education
d. Safety
e. Time
f. Lack of space
g. Lack of recycling facilities
h. Lack of support from hospital/OR leadership
i. Other (please specify):

13. Which of the following is currently the biggest barrier to recycling in the OR? (choose only one)
a. Staff attitudes
b. Cost
c. Inadequate information/education
d. Safety
e. Time
f. Lack of space
g. Lack of recycling facilities
h. Lack of support from hospital/OR leadership
i. $\quad$ Other (please specify):

14. Which of the following do you perceive as barriers to other sustainability efforts in the OR?
a. Staff attitudes
b. Cost
c. Inadequate information/education
d. Safety
e. Time 

f. Lack of space
g. Lack of facilities
h. Lack of support from hospital/OR leadership
i. Other:

15. To increase recycling in the OR, which of the following are you willing to provide? (Choose all that apply)
a. Time to educate others
b. Time to educate myself
c. Funds to educate others
d. Funds to educate myself
e. Time for research
f. Funds for research
g. None of the above
h. Other (please specify):

\section{Future efforts}

16. To your knowledge, does your department have any plans to increase sustainability efforts in any of the following areas:

a. Recycling

b. Choosing anesthetic gases based on their environmental footprint (including managing fresh gas flows and carrier gases)

c. Using anesthetic gas capture/reflection modalities

d. Using prefilled medication syringes

e. Using reusable products (gowns, LMA, anesthesia circuits, etc.) instead of singleuse products

f. Reprocessing single-use medical equipment

g. Using reusable sharps containers

h. Donating unused medical equipment and supplies to medical missions

i. Partnering with industry to promote greener packaging practices

j. Appropriate segregation of biohazardous and nonhazardous waste

k. Evening shut-off of anesthesia machine and other equipment in the OR

1. I am not aware of any such plans

m. Other (please specify): 
17. How likely are you to seek more information on the topic of environmentally sustainable anesthesia practice?

a. Very unlikely - Unlikely - I don't know - Likely - Very likely

18. In your opinion, which of the following would be the most valuable methods to increase awareness of recycling and environmental sustainability efforts among anesthetists?

(choose one)

a. Formal curriculum during training

b. Workshop

c. Online e-module

d. Conference lecture

e. Journal club

f. Peer-to-peer discussions

g. Independent reading

h. Other (please specify):

19. Do you have any further comments regarding recycling, environmental sustainability or any other topics covered in this survey?

\section{References}

1. Landrigan PJ, Fuller $R$, Acosta NJ, et al. The Lancet Commission on pollution and health. Lancet 2018; 391: 462-512.

2. Natural Resources Canada. Energy Use Data Handbook (1990 to 2015)] - 2018. Available from URL: http://oee.nrcan.gc.ca/ corporate/statistics/neud/dpa/menus/trends/handbook/tables.cfm (accessed October 2018).

3. Eckelman MJ, Sherman J. Environmental impacts of the U.S . health care system and effects on public health. PLoS One 2016; 11: e0157014.

4. McGain F, Naylor C. Environmental sustainability in hospitals a systematic review and research agenda. J Health Serv Res Policy 2014; 19: 245-52.

5. McGain FM, Hendel SA, Story DA. An audit of potentially recyclable waste from anaesthetic practice. Anesth Intensive Care 2009; 37: 820-3.

6. Tudor TL, Marsh CL, Butler S, Van Horn JA, Jenkin LE. Realising resource efficiency in the management of healthcare waste from the Cornwall National Health Service (NHS) in the UK. Waste Manag 2008; 28: 1209-18.

7. Healthier Hospitals Initiative. Leading communities to a healthier future - 2014 Milestone Report. Available from URL: https://practicegreenhealth.org/sites/default/files/upload-files/fnl_ hhi_milestone_report_061015_lores.pdf (accessed October 2018).

8. Hutchins DC, White SM. Coming round to recycling. BMJ 2009; 338: b609.

9. McGain F, Story D, Kayak E, Kashima Y, McAlister S. Workplace sustainability: the "cradle to grave" view of what we do. Anesth Analg 2012; 114: 1134-9.

10. McGain F, White S, Mossenson S, Kayak E, Story D. A survey of anesthesiologists' views of operating room recycling. Anesth Analg 2012; 114: 1049-54.
11. Ard JL, Tobin K, Huncke T, Kline R, Ryan SM, Bell C. A survey of the American Society of Anesthesiologists regarding environmental attitudes, knowledge, and organization. A A Case Rep 2015; 6: 208-16.

12. Raosoft Inc. Sample size calculator - 2004. Available from URL: http://www.raosoft.com/samplesize.html (accessed October 2018).

13. McGain F, Jarosz KM, Nguyen MN, Bates S, O'Shea CJ. Auditing operating room recycling: a management case report. A Case Rep 2015; 5: 47-50.

14. World Health Organization. Safe management of wastes from health-care activities, 2014. Available from URL: http://www. who.int/water_sanitation_health/publications/wastemanag/en/ (accessed October 2018).

15. Wan EL, Xie L, Barrett M, et al. Global public health impact of recovered supplies from operating rooms: a critical analysis with national implications. World J Surg 2015; 39: 29-35.

16. Cockerell $J$. Making donations of medical equipment work. The Lancet Global Health Blog - 2014. Available from URL: http:// globalhealth.thelancet.com/2014/01/20/making-donationsmedical-equipment-work (accessed October 2018).

17. Germain $S$. The ecological footprint of Lions Gate Hospital. Healthc Q 2001; 5: 61-6.

18. London Health Sciences Centre. London Health Sciences Centre's Footprint - 2009. Available from URL: http://www. lhsc.on.ca/About_Us/Ecological_Stewardship/Footprinting/ LHSC_footprint.htm (accessed October 2018).

19. Mejia EA, Sattler B. Starting a health care system green team. AORN J 2009; 90: 33-40.

20. Chenven L, Copeland D. Front-line worker engagement: greening health care, improving worker and patient health, and building better jobs. New Solut 2013; 23: 327-45. 
21. Topf M. Psychological explanations and interventions for indifference to greening hospitals. Health Care Manage Rev 2005; 30: 2-8.

22. Wormer BA, Augenstein VA, Carpenter CL, et al. The green operating room: simple changes to reduce cost and our carbon footprint. Am Surg 2013; 79: 666-71.

23. Dunphy JL. Healthcare professionals' perspectives on environmental sustainability. Nurs Ethics 2014; 21: 414-25.

24. Soares SR, Finotti AR, da Silva VP, Alvarenga RA. Applications of life cycle assessment and cost analysis in health care waste management. Waste Manag 2013; 33: 175-83.

25. Lee BK, Ellenbecker MJ, Moure-Eraso R. Analyses of the recycling potential of medical plastic wastes. Waste Manag 2002; 22: 461-70.

26. Pogorzelska-Maziarz M. Relationship between sharps disposal containers and Clostridium difficile infections in acute care hospitals. Am J Infect Control 2015; 43: 1081-5.

27. Sherman J, Le C, Lamers $V$, Eckelman $M$. Life cycle greenhouse gas emissions of anesthetic drugs. Anesth Analg 2012; 114: 108690.

28. Yang $Y$, Rivera AJ, Fortier CR, Abernathy JH 3rd. A Human factors engineering study of the medication delivery process during an anesthetic: self-filled syringes versus prefilled syringes. Anesthesiology 2016; 124: 795-803.

29. Eckelman M, Mosher M, Gonzalez A, Sherman J. Comparative life cycle assessment of disposable and reusable laryngeal mask airways. Anesth Analg 2012; 114: 1067-72.

30. Overcash M. A comparison of reusable and disposable perioperative textiles: sustainability state-of-the-art 2012. Anesth Analg 2012; 114: 1055-66.

31. Grimmond T, Reiner S. Impact on carbon footprint: a life cycle assessment of disposable versus reusable sharps containers in a large US hospital. Waste Manag Res 2012; 30: 639-42.

32. McGain F, McAlister S, McGavin A, Story D. A life cycle assessment of reusable and single-use central venous catheter insertion kits. Anesth Analg 2012; 114: 1073-80.

33. American Society of Anesthesiology Task Force on Environmental Sustainability Committee on Equipment and Facilities. Greening the Operating Room and Perioperative Arena: Environmental Sustainability for Anesthesia Practice. American Society of Anesthesiologists - 2017. Available from URL: https://www.asahq.org/resources/resources-from-asacommittees/environmental-sustainability/greening-the-operatingroom (accessed October 2018). 